\title{
MULTI-OFFICE INCUMBENCY ADVANTAGE: POLITICAL CAREERS IN BRAZIL
}

Leandro De Magalhães

Salomo Hirvonen

Discussion Paper 15 / 662

22 June 2015

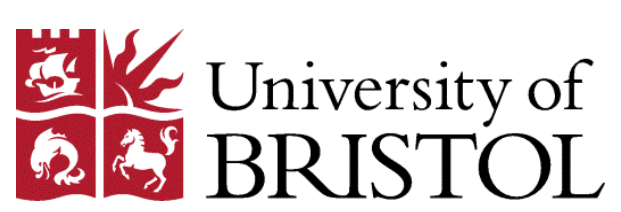

Department of Economics

University of Bristol

8 Woodland Road

Bristol BS8 1TN

United Kingdom 


\title{
Multi-Office Incumbency Advantage: Political Careers in Brazil*
}

\author{
Leandro De Magalhães ${ }^{\dagger}$ and Salomo Hirvonen \\ University of Bristol
}

June 19, 2015

\begin{abstract}
Incumbency may have effects on a political career that go beyond increasing the probability of reelection. In particular, incumbency may affect the probability of winning different political offices. So far, the literature has not looked at these multi-office incumbency effects. In contexts where politicians move frequently to other offices, ignoring multi-office advantages may generate biased estimates of the true effect of holding a political office on the success of one's career. We define Multi-Office Incumbency Advantage and study it using a novel data set that tracks all Brazilian politicians, from local councillor to federal legislator, from 1994 to 2010. Furthermore, we use our results to evaluate two standing hypothesis regarding Brazilian politics. The first is that there is an incumbency disadvantage in Brazil. The second is the hypothesis
\end{abstract}

${ }^{*}$ A previous version of this paper circulated under the title 'Incumbency Effects in Brazilian Mayoral Elections: A Regression Discontinuity Design'.

${ }^{\dagger}$ e-mail: leandro.demagalhaes@bristol.ac.uk 
that holding a federal legislative office is a spring board to becoming a Mayor.

We find no support for either.

JEL:D70, D72, J00.

Keywords: Incumbency Advantage, Political Careers, Regression Discontinuity Design, Brazil. 
One of the core assumptions in political science and political economy models is that politicians maximize their probability of reelection for the same office (Mayhew (1974)). This is perfectly valid for the US Congress, where incumbents rerun and are reelected with rates of approximately $90 \%$ at each electoral cycle. 1 What if the number of incumbents who seek to be elected for other offices were substantial? Models would have to allow for a share of politicians to maximize their probability of reelection whereas another share maximizes their probability of moving to other offices. A state wide representative (Senator in the US or any Brazilian legislator) may follow a very different strategy if their objective is to become a mayor instead of being reelected for Congress. Funds may be geographically concentrated to a particular municipality, adherence to national party lines may be weaker among those that wish to become mayors, career concerns within the structure of Congress will matter less, and so on 2 Moreover, models that assume purely reelection incentives have been used to explain the development of institutions in the American Congress $3^{3}$ Empirically determining the share of legislators interested in other objectives than reelection and the implicit ranking of political offices will help us understand not only differential career choices, but also differential institutional development across countries 4

${ }^{1}$ Virtually all of those who leave Congress stop running for elected office. See Herrick and Nixon (1996), Hall and Van Houweling (1995), and Diermeier et al. (2005).

${ }^{2}$ See Ames (1995) and Pereira and Renno (2003) for a discussion of the electoral strategies of Brazilian legislators. See Epstein et al. (1997) for a comparison between political incentives and institutions in the US and Japan.

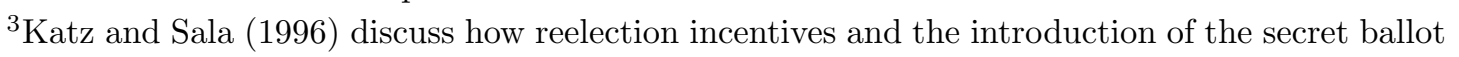
led to the rule that reelected incumbent representatives were reassigned to the same committee.

${ }^{4}$ Cunow et al. (2012) discuss how the the choice made by the members of the Brazilian constitutional assembly in 1988 were driven by their electoral objectives. 
In particular, if politicians seek to switch offices in large numbers, it becomes necessary to broaden the definition of incumbency advantage away from the traditional focus on reelection for the same office. If successful incumbents chose to run for higher offices in the next election, we may underestimate the true incumbency advantage. For example, the traditional reelection estimate may indicate a incumbency disadvantage, whereas, if we bring the other political offices into the analysis we may find that being the incumbent is an advantage for one's political career (e.g., Eggers and Spirling (2014) shows some evidence that part of the explanation for an incumbency disadvantage in victorian Britain was that successful representatives may move to safer seats or to un-elected offices). If runners-up chose to run for higher offices in the next election and often win, we may overestimate the true incumbency advantage. The traditional reelection estimate may indicate a high incumbency advantage, but it may fail to acknowledge that runners-up simply chose to run for other equally important political offices. We illustrate this case with Brazilian electoral data in this paper. Thus, in political systems where politicians switch offices frequently, it is necessary to account for their movements across political offices in order to understand whether holding a particular office is an advantage or a disadvantage for a politician's career. The main contribution of this paper is to generalize the concept of incumbency advantage to a multi-office incumbency advantage.

The concept of multi-office incumbency advantage builds on the concept of incumbency advantage as proposed by Erikson (1971), Levitt and Wolfram (1997), Ansolabehere et al. (2000), Lee (2001), and in particular by De Magalhães (2015). In these papers, incumbency advantage is identified by comparing how well a given politician does in a given election in two different scenarios, one of which is a counterfactual: i) the politician is the current incumbent, ii) the same politician runs in the 
same election but is not the incumbent $5^{5}$ Regression discontinuity design (RDD) is an appropriate and often used method to empirically identify incumbency advantage. We estimate the multi-office incumbency advantage with RDD as well ${ }^{6}$

We use a novel Brazilian data set to illustrate how the concept of multi-office incumbency advantage may help us understand the potential biases of omitting relevant political offices when estimating incumbency advantage. The data set we have compiled includes the electoral results for all politicians that ever ran for any office in Brazil from 1994 to 2010.7 We are able to follow these politicians over time as they move from one office to another. Moreover we also have information on all candidates that ran and lost, even if they never held an elected office. We find that politicians do move across political offices in all directions. We show this with a transition matrix indicating where all Brazilian politicians holding any given office go next. $]^{8}$

We show there is a clear incumbency advantage - multi-office and reelection

\footnotetext{
${ }^{5}$ Note that our definition differs from what Gelman and King (1990) and Cox and Katz (1996) define as incumbency advantage, which is the difference between the vote share of a party in a given district when it fields the incumbent politician and the vote share of the same party when the race in that district is an open-contest. Note that we deliberately cite the working paper version of Lee (2008), as the focus on the published version is on party incumbency advantage. For a discussion on individual vs. party incumbency effects see Fowler and Hall (2014)

${ }^{6}$ For a discussion on the validity of RDD across countries, see Eggers et al. (2015).

${ }^{7}$ These data are available on the Tribunal Superior Eleitoral (TSE) website but they lack individual identifiers, which we had to create using their names, date-of-birth, state of origin, and municipality.

${ }^{8}$ Our data allows us to generalize the results in Pereira and Rennó (2004). Their focus is solely on the transition from federal legislators into other state or federal offices. Transitions in the other direction are not studied. Municipal offices are not included in their data set, neither are the election years of 1994 and 1996.
} 
- among state and federal legislators in Brazil. We also show that the reelection estimates of incumbency advantage would overestimate the true incumbency advantage. This is so because more runners-up than incumbents (in close elections) go on to become mayors in the midterm elections. In elections for mayors and for local councillors the reelection estimates of incumbency advantage and the multi-office incumbency advantage do not differ significantly $!^{9}$ This is not surprising as the average municipality is small and few local politicians are able to brake into state and federal political careers. We find a small incumbency advantage for local councillors and the estimates of incumbency advantage for mayors change across electoral cycles (the estimates are stable for all other offices), but overall we find no evidence for a clear incumbency advantage or disadvantage for mayors.

Our results on incumbency advantage in Brazil contrasts with recent research that suggests there is an incumbency disadvantage in Brazilian mayoral elections (Brambor and Ceneviva (2011) and Klašnja and Titiunik (2013)), and more generally in developing countries $\$ 10$ Our results also differ from Samuels (2003), who documents a decline on the probability of reelection over time for Brazilian legislators and concludes there is no incumbency advantage among federal legislator 11

\footnotetext{
${ }^{9} \mathrm{RDD}$ is not suitable to estimate incumbency advantage for senators and governors: the sample is too small.

${ }^{10}$ De Magalhães (2015) discusses potential issues with the estimates in Brambor and Ceneviva (2011); and also in Uppal (2008) and Linden (2004), who suggest there is an incumbency disadvantage in India. The results in Klašnja and Titiunik (2013) of a party incumbency disadvantage in Brazilian mayoral elections are consistent with our results. The possibility of a negative incumbency advantage for parties co-existing with a positive incumbency advantage for individuals is discussed in De Magalhães (2015).

${ }^{11}$ The definition of incumbency advantage in Samuels (2003) does not correspond to the definition of incumbency advantage used here or in the US context (Erikson (1971), Levitt and Wolfram (1997), Ansolabehere et al. (2000), Lee (2001)) and therefore, can not be used for cross-country
} 
Finally, the data also allow us to test one of the main tenets of Ambition Theory as applied to Brazil by Samuels (2003) ${ }^{12}$ This is the hypothesis that Brazilian federal legislators use their office as a spring board for executive office. It is no surprise that a federal legislator may aspire to become governor or senator 13 The particularity about Brazil according to Samuels (2003) is that running for mayor should be seen as progressive ambition 14 Our estimates of multi-office incumbency advantage show that becoming a federal legislator has no causal impact on the probability of becoming a mayor. Both bare winner legislators and runners-up are as likely to subsequently run for mayor and to become one. This result does not support the hypothesis of legislative offices being a stepping stone for mayoral office. On the other hand, we also estimate the multi-office incumbency advantage in the subsample of municipalities we denote "revolving-door municipalities", where local politicians have also held state or federal posts. In the revolving-door municipalities we find that considerably more runners-up than incumbents go on to become state and federal legislators. This suggests that legislative office (in these municipalities) is a career choice for those who do not manage to become mayors. This result, in turn, lends support to the categorization of politician ideal types proposed in Samuels (2003). Particulary, it supports the presence of "municipal-directed" politicians, who become legislators in order to stay alive in politics until they can pursue their goal of becoming mayor.

In Section 1 of the paper we formally define Multi-Office Incumbency Advantage. comparison. The decline in reelection rates is indeed puzzling and deserves further investigation, but this goes beyond the scope of our paper.

${ }^{12}$ Ambition Theory and the concepts of progressive, static ambition, and regressive ambition were first proposed by Schlesinger (1966).

${ }^{13}$ Rohde (1979) points out that in the absence of risk House representatives would chose to move to the Senate.

${ }^{14}$ See Samuels (2003), pg. 38 Table 2.2 and Leoni et al. (2004). 
In Section 2 we describe the data and present the transition matrix for all political offices in Brazil. In Section 3 we present our estimates of the multi-office incumbency advantage and discuss the application of ambition theory to Brazil. In Section 4 we conclude.

\section{Multi-Office Incumbency Advantage}

\section{Reelection incumbency advantage}

First, let us define the traditional 'reelection' incumbency advantage using the potential outcomes framework. Let $M$ denote the set of all elected offices in a polity. Elections for all offices in $M$ take place concurrently in every period ${ }^{15}$ In each election period a candidate $i$ can only run for one office $m \in M$. Let $D_{i}^{m}$ be an indicator variable for politician $i$ winning the election for a given office $m$ in period $t$. We condition on candidates who run for a given office $m$. Winning the election for office $m$ in period $t$ makes candidate $i$ the incumbent, i.e. candidate $i$ receives the treatment and $D_{i}^{m}=1$. If candidate $i$ loses the election for office $m$ in period $t$, candidate $i$ is assigned to the control group and $D_{i}^{m}=0$.

In period $t+1$ elections for all offices in $M$ take place again. The traditional reelection incumbency advantage is defined by focusing our attention solely on the same office $m$ in period $t+1$. The outcome variable is defined as follows. Let the indicator variable $Y_{m, i}^{m}$ be equal to 1 if politician $i$ runs for office $m$ and wins in period $t+1$. The over-script $m$ indicates that the candidate $i$ ran for office $m$ in period $t$ and the under-script $m$ indicates candidate's $i$ outcome regarding office $m$ in period $t+1$. Let $Y_{m, i}^{m}$ be equal to 0 otherwise (i.e., if politician $i$ does not run for any office

\footnotetext{
${ }^{15}$ This assumption is for purposes of clarity. We discuss in Section 3 how to adapt the definition to include staggered elections for different posts.
} 
in $t+1$, runs for an office other than $m$, or runs for office $m$ and loses). ${ }^{16}$ There are two potential outcomes for each politician $i$ who ran for office $m$ in period $t: Y_{m, i, 1}^{m}$ is the electoral result for office $m$ in $t+1$ of politician $i$ if she is the incumbent in office $m$, and $Y_{m, i, 0}^{m}$ is the electoral result for office $m$ in $t+1$ of politician $i$ if she is the non-incumbent in office $m$ (i.e., $i$ ran and lost the election for office $m$ in period $t)$.

With the potential outcomes described above, we can define the traditional reelection incumbency advantage: the average treatment effect of incumbency in office $m$ on the probability of running and being elected for the same office $m$ in the next election, $E\left[Y_{m, i, 1}^{m}-Y_{m, i, 0}^{m}\right]$. The most common method to estimate this definition of incumbency advantage has been using a regression discontinuity design with bare winners and bare losers of an election in $t$ and comparing how they do in their probability of winning the same office in $t+1$ (see Lee (2001), Linden (2004), and De Magalhães (2015)).

\section{Across-office incumbency advantage}

The definition of incumbency advantage can be extended to an 'across-office' incumbency advantage. We still interpret the election for office $m$ in period $t$ as the 'experiment', but now we focus on the election result for another office in $t+1$ (e.g., the causal effect of being a mayor on the probability of becoming a House

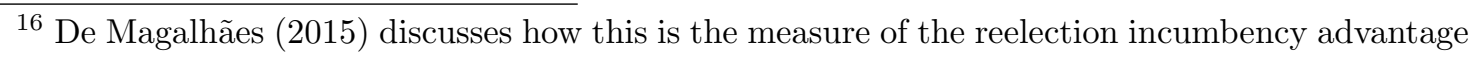
that should be used for comparative purposes. The reason is the choice to rerun, retire, or run for other offices is strategic. This means that we can only estimate the causal effect of incumbency unconditional on those choices. It also means that we can not use the vote share as our outcome of interest. Moreover, rerunning rates may vary across countries and if we condition on rerunning we generate incumbency advantage estimates that are not comparable across political systems.
} 
representative). Treatment is still defined by the variable $D_{i}^{m}$. The outcome of interest is now different and defined as $Y_{k, i}^{m}$, where the upper-script $m$ indicates that the allocation of treatment was determined by an election for office $m$ and the under-script $k$ indicates that the outcome is measured in an election for office $k \in M$, $k \neq m$. To be explicit, $Y_{k, i}^{m}$ is equal to 1 if politician $i$ runs for office $k$ and wins in period $t+1$ and $Y_{k, i}^{m}$ is equal to 0 otherwise (i.e., if politician $i$ does not run for any office in $t+1$, runs for an office other than $k$ - including office $m$ - or runs for office $k$ and loses). There are two potential outcomes for each politician $i$ who ran for office $m$ in period $t: Y_{k, i, 1}^{m}$ is the electoral result for office $k$ in $t+1$ of politician $i$ if she is the incumbent in office $m$, and $Y_{k, i, 0}^{m}$ is the electoral result for office $k$ in $t+1$ of politician $i$ if she is the non-incumbent in office $m$ (i.e., $i$ ran and lost the election for office $m$ in period $t$ ). The across-office incumbency advantage is defined as $E\left[Y_{k, i, 1}^{m}-Y_{k, i, 0}^{m}\right]$.

\section{Multi-office incumbency advantage}

Different politicians may pursue different political careers and it may be useful to measure whether a particular office helps one build one's political career in general (i.e., across offices). For this purpose we must rank political offices accordingly. Let the set $W^{m}$ be a subset of the set of all offices $M$. The set $W^{m}$ consists of political offices that rank at least as high as office $m \in M$. As an example, in the case of estimating the effect of holding a particular office $m$ (i.e., House representative), the researcher may decide to include House representatives and Senators in $W^{m}$, whereas elected city councillors are not included in $W^{m}$. Winning an office in $W^{m}$ will be counted as an electoral victory and winning an office not in $W^{m}$ will be counted as a defeat or as having not run at all.

More formally, the outcome of interest for the multi-office incumbency advantage 
is $Y_{w, i}^{m}=\sum_{k} I_{k \in W^{m}} \times Y_{k, i}^{m}$, where $I_{k \in W^{m}}$ is an indicator function that takes value 1 if the office $k$ is in $W^{m}$ - we assume that a politician can only run for one office at any election. The treatment is still defined by the variable $D_{i}^{m}$ and we interpret the election for a given office $m$ in period $t$ as the 'experiment', but now we can look at election results for all offices in $t+1$ deemed relevant by the researcher. The outcome of interest $Y_{w, i}^{m}$ takes values 1 if the politician $i$ wins any office in $W^{m}$ and takes value 0 otherwise (i.e., if politician $i$ does not run for any office, runs for an office not in $W^{m}$ and wins or runs for any office in $M$ and loses). There are two potential outcomes for each politician $i$ who ran for office $m$ in period $t: Y_{w, i, 1}^{m}$ is the multi-office result in $t+1$ of politician $i$ if she is the incumbent in office $m$, and $Y_{k, i, 0}^{m}$ is the multi-office result in $t+1$ of politician $i$ if she is the non-incumbent in office $m$ (i.e., $i$ ran and lost the election for office $m$ in period $t$ ).

Definition of the Multi-Office Incumbency Advantage. The average treatment effect of incumbency of office $m \in M$ on the probability of running and being elected for any office $k \in W^{m}$ is: $E\left[Y_{w, i, 1}^{m}-Y_{w, i, 0}^{m}\right]$.

\section{Data}

Electoral data and information about candidates characteristics was obtained from the National Electoral Office (Tribunal Superior Eleitoral). The data set comprises all elections held in Brazil from 1994 to 2010. Candidate information includes vote share, party affiliation, age, education, marital status, and gender. We have used the candidate's name, social security number ( $c p f)$, and date of birth to match the same 
individual in different elections. This allows us to track their political careers ${ }^{17}$

In Table 1 we present the summary statistics of our data. The average vote share of a candidate for each office varies from $36 \%$ for mayor to $0.3 \%$ for the average state legislator. The average age of candidates is in the 40s for all offices except senator, with the average age of 51 . The most educated candidates are those for Senators, followed by Governor, federal legislators, state legislators, mayors, and councillor. Less than $50 \%$ of councillors have some tertiary education. Female candidates are approximately $10 \%$ of candidates except for local councillor, where they represent 20\%. More than $75 \%$ of all candidates are married, the three main parties (i.e., PT, PSDB, and PMDB) represent $10 \%$ of the candidates each. Approximately $10 \%$ of candidates for every office has had previous experience in local offices, except Mayors, for whom $30 \%$ has held local office previously. A negligible amount of candidates for councillors has had previous state (or federal) office experience, $2 \%$ for candidates for mayor, $7 \%$ for state legislators, $11 \%$ for federal legislators, $22 \%$ for senators, and $25 \%$ for candidates for governor.

Brazilian politicians have a chance to run for office every 2 years. Local elections for mayor and for municipal councillor are held every four years, in our sample these are: 1996, 2000, 2004, and 2008. State-wide and federal elections for the legislative chambers (Federal House and Senate, and state Houses) and executive offices (governor and president) are also held every four years: 1994, 1998, 2002, 2006, and 2010. Executive office holders (mayors, governors, and presidents) have to step down before running for legislative office, but they do not need to step down

\footnotetext{
${ }^{17}$ There are some missing values for key variables such as vote share among local councillors and some mayors, see Table 11 in the appendix. The information on coalition is missing for municipal councillors in the 1996 election and it is not available for all states for the 1994 state legislative elections.
} 
Table 1: Summary Statistics: characteristics of all candidates

\begin{tabular}{|c|c|c|c|c|c|c|}
\hline Ran for: & Councillor & Mayor & State Legislator & Federal Legislator & Senator & Governor \\
\hline \multirow[t]{2}{*}{ vote share } & 0.017 & 0.361 & 0.003 & 0.007 & 0.122 & 0.159 \\
\hline & {$[0.017 ; 0.017]$} & {$[0.359 ; 0.362]$} & {$[0.003 ; 0.003]$} & {$[0.007 ; 0.007]$} & {$[0.113 ; 0.131]$} & {$[0.144 ; 0.174]$} \\
\hline \multirow[t]{2}{*}{ CV of Votes } & 0.98 & 0.6 & 1.76 & 2.03 & 1.22 & 1.45 \\
\hline & {$[0.98 ; 0.98]$} & {$[0.59 ; 0.61]$} & {$[1.75 ; 1.76]$} & {$[2.02 ; 2.04]$} & {$[1.2 ; 1.24]$} & {$[1.43 ; 1.47]$} \\
\hline \multirow[t]{2}{*}{ Age } & 42.7 & 47.2 & 45 & 46.9 & 51.2 & 49.4 \\
\hline & {$[42.7 ; 42.7]$} & {$[47.1 ; 47.3]$} & {$[44.9 ; 45.1]$} & {$[46.8 ; 47.1]$} & {$[50.6 ; 51.8]$} & {$[48.7 ; 50.1]$} \\
\hline \multirow[t]{2}{*}{ Education } & 0.46 & 0.72 & 0.82 & 0.87 & 0.95 & 0.92 \\
\hline & {$[0.46 ; 0.46]$} & {$[0.71 ; 0.73]$} & {$[0.82 ; 0.82]$} & {$[0.87 ; 0.89]$} & {$[0.93 ; 0.96]$} & {$[0.94 ; 0.97]$} \\
\hline \multirow[t]{2}{*}{ Female } & 0.2 & 0.09 & 0.12 & 0.1 & 0.12 & 0.1 \\
\hline & {$[0.2 ; 0.21]$} & {$[0.09 ; 0.09]$} & {$[0.12 ; 0.13]$} & {$[0.09 ; 0.11]$} & {$[0.1 ; 0.14]$} & {$[0.08 ; 0.12]$} \\
\hline \multirow[t]{2}{*}{ Single } & 0.24 & 0.12 & 0.22 & 0.19 & 0.11 & 0.12 \\
\hline & {$[0.24 ; 0.24]$} & {$[0.12 ; 0.12]$} & {$[0.21 ; 0.22]$} & {$[0.19 ; 0.2]$} & {$[0.09 ; 0.13]$} & {$[0.1 ; 0.14]$} \\
\hline \multirow[t]{2}{*}{ PT } & 0.08 & 0.1 & 0.08 & 0.09 & 0.09 & 0.11 \\
\hline & {$[0.08 ; 0.08]$} & {$[0.1 ; 0.1]$} & {$[0.08 ; 0.08]$} & {$[0.09 ; 0.1]$} & {$[0.08 ; 0.11]$} & {$[0.8 ; 0.13]$} \\
\hline \multirow[t]{2}{*}{ PMDB } & 0.13 & 0.18 & 0.08 & 0.09 & 0.1 & 0.1 \\
\hline & {$[0.13 ; 0.13]$} & {$[0.18 ; 0.18]$} & {$[0.08 ; 0.08]$} & {$[0.08 ; 0.09]$} & {$[0.09 ; 0.12]$} & {$[0.08 ; 0.12]$} \\
\hline \multirow[t]{2}{*}{ PSDB } & 0.1 & 0.13 & 0.07 & 0.07 & 0.07 & 0.08 \\
\hline & {$[0.1 ; 0.1]$} & {$[0.13 ; 0.13]$} & {$[0.06 ; 0.07]$} & {$[0.06 ; 0.07]$} & {$[0.05 ; 0.08]$} & {$[0.06 ; 0.1]$} \\
\hline \multirow[t]{2}{*}{ Local office prev. } & 0.11 & 0.3 & 0.12 & 0.1 & 0.08 & 0.08 \\
\hline & {$[0.11 ; 0.11]$} & {$[0.29 ; 0.3]$} & {$[0.12 ; 0.13]$} & {$[0.09 ; 0.1]$} & {$[0.06 ; 0.09]$} & {$[0.07 ; 0.1]$} \\
\hline \multirow[t]{2}{*}{ Legis. office prev. } & 0.0002 & 0.02 & 0.07 & 0.11 & 0.22 & 0.25 \\
\hline & {$[0.0002 ; 0.0002]$} & {$[0.02 ; 0.02]$} & {$[0.07 ; 0.07]$} & {$[0.1 ; 0.11]$} & {$[0.19 ; 0.24]$} & {$[0.21 ; 0.28]$} \\
\hline number of obs. & 1347402 & 61202 & 49917 & 19219 & 1074 & 773 \\
\hline
\end{tabular}

Note: Sample consists of pooled elections; years 1994, 1998, 2002, 2006, and 2010 for State Deputy and Federal Deputy elections, and years 1996, 2000, 2004, and 2008 for Councillor and Mayoral elections. Local office previously is defined as having previously won Councillor, Mayor, or Vice-Mayor election. Legislative office previously is defined as having previously won State Deputy, Federal Deputy, Senator, Supplement Senator, Governor or Vice-Governor Election. 95\% Confidence Interval is given in the parenthesis. 
when running for reelection. Legislators and municipal councillors may run for any office without stepping down. In particular, this setup allows legislators to run for mayor two years into their term with no risk of being left without a political job.

Elections for mayor are decided by simple majority rule for small municipalities ${ }^{18}$ Elections for municipal councillors and for state and federal legislators are decided by an open-list proportional system. Each individual vote is counted twice: once for the coalition and once for the individual. The coalition count decides how many seats will be assigned for each coalition, and the individual count decides the within coalition ordering of candidates; those at the top of the list are elected 19

In Table 2 we have summarized where politicians holding any given office go next. In the diagonal entries, we can see the reelection rates.20 The first thing to note is that reelection rates are highest among federal legislators (54\%), followed by state legislators (50\%), municipal councillor (42\%), mayors $(38 \%)$, governors $(31 \%)$, and senators $(22 \%)$. The low reelection rates for mayors and governors is not surprising as both offices face a term limit of two consecutive mandates - there are no term limits for other offices. The reelection rates provide one clear raking across political offices with federal legislators on top. An alternative would be to rank offices ac-

\footnotetext{
${ }^{18}$ In mayoral election in municipalities with more than 200,000 inhabitants and in gubernatorial elections, a run-off is required if the first place candidate has less than $50 \%$ of the valid votes.

${ }^{19}$ The system also allows for a party vote that does to specify an individual. This is not very common and does not affect our estimates. Note that the relevant political unit in each election is a coalition of parties, not the parties themselves. These coalitions differ in their composition over time and across geographical areas.

20 Table 2 is constructed as a summary of each year's transition Tables that can be seen in the on-line appendix. The diagonal entries also include cases in which a legislators did not get reelected straight away, but instead waited 4 years and then went back to Congress. The numbers of such cases are negligible.
} 
cording to the number of politicians who do not retire from politics by the end of their term. Such a raking would place mayors, local councillors, and senators at a similar level, with less than $50 \%$ winning any office in the future. This is well below state legislators, federal legislators, and governors, with more than $65 \%$ winning an subsequent office. 
Table 2: Next office held by current politicians

\begin{tabular}{|c|c|c|c|c|c|c|c|c|c|c|}
\hline To: & Councillor & Mayor & Vice-Mayor & State Deputy & Federal Deputy & Senator & Sup. Senator & Governor & Vice-Governor & No office \\
\hline \multicolumn{11}{|l|}{ From: } \\
\hline Councillor & 0.42 & 0.009 & 0.02 & 0.003 & 0.001 & 0 & 0 & 0 & 0 & 0.547 \\
\hline Mayor & 0.009 & 0.381 & 0.013 & 0.011 & 0.004 & 0 & 0 & 0.001 & 0 & 0.58 \\
\hline Vice-Mayor & 0.058 & 0.074 & 0.205 & 0.003 & 0.001 & 0 & 0 & 0 & 0 & 0.658 \\
\hline State Deputy & 0.014 & 0.075 & 0.008 & 0.504 & 0.054 & 0.003 & 0.002 & 0.001 & 0.003 & 0.332 \\
\hline Federal Deputy & 0.013 & 0.053 & 0.006 & 0.017 & 0.54 & 0.017 & 0.002 & 0.004 & 0.005 & 0.341 \\
\hline Senator & 0.012 & 0.037 & 0 & 0.006 & 0.075 & 0.224 & 0.012 & 0.087 & 0.012 & 0.534 \\
\hline Sup. Senator & 0.025 & 0.013 & 0 & 0 & 0.025 & 0.013 & 0.063 & 0 & 0 & 0.863 \\
\hline Governor & 0 & 0.031 & 0 & 0.01 & 0.071 & 0.245 & 0 & 0.306 & 0 & 0.337 \\
\hline Vice-Governor & 0 & 0.023 & 0 & 0.068 & 0.068 & 0.023 & 0.023 & 0.091 & 0.091 & 0.614 \\
\hline
\end{tabular}

Notes: Columns refer to next office gained. Cells refer to transition probabilities. The sample consists of pooled elections; years 1994, 1998, 2002, 2006, and 2010 for State Deputy, Federal Deputy Governor and Senator elections, and years 1996, 2000, 2004, and 2008 for Councillor and Mayoral elections. 
Another noticeable feature in Table 2 is that a significant share of legislators go on to successfully hold local offices. Rows 4 and 5 of Table 2 reveal to us that $4 \%$ of federal legislator and $6 \%$ of state legislators go on to become mayors. Approximately $5 \%$ of state legislators manage the upward transitions to federal legislators. Among senators, $9 \%$ go on to become governors in a arguably upward trajectory, but $7.5 \%$ go on to become federal legislators and $4 \%$ go on to become mayors. A considerable share of governors go on to the Senate (24.5\%), $7 \%$ become federal legislators, and $3 \%$ become mayors. Given the large number of small municipalities, it is no surprise that the movement on the other direction, i.e. from local offices to state or federal, are negligible at less than $0.5 \%$. For completeness we also include the offices of vice-mayor, vice-governor, and vice-senator in the Table 2 , the definition of electoral success may also include holding the these offices ${ }^{21}$

\footnotetext{
${ }^{21}$ Vice-senators or Suplentes do not hold a political office per se but often go on to become senators for periods of time in which the elected senators holds executive offices such as cabinet minister, or resign.
} 


\section{Multi-Office Incumbency Advantage in Brazil}

\subsection{Multi-Office Incumbency Advantage}

In this paper we study the incumbency advantage of holding the following Brazilian political offices, $M=\{$ federal legislator, state legislator, mayor, municipal councillor, senator, governor $\}$. For all offices, except that of local councillor, we let $W^{m}=\{$ federal legislator, state legislator, mayor, senator, governor $\}$, that is, we count becoming a local councillor as an electoral defeat, but winning any other office as an electoral success ${ }^{22}$ When estimating the multi-office incumbency effect of local councillors we include reelection as a victory.

An important feature of Brazilian politics is that local and state-federal elections are staggered every two years. Candidates in a election in year $t$ can run for another office in year $t+2$ before attempting reelection in year $t+4$. We defined "multi-office success $(\mathrm{t}+4)$ " as taking value 1 if the candidate who ran in year $t$ subsequently wins one of the following offices within the next four years: mayor, senator, governor, state legislators, and federal legislator. Winning the office of councillor is coded as a 0 . A defeat for all offices and a candidate who does not run for any office is also coded as a zero. "Multi-office success $(\mathrm{t}+6)$ " extends the period to six years. These two alternative definitions are necessary in the Brazilian case where politicians can only run for reelection four years after being elected, but can run for other offices two, four, or six years after being elected.

The two methods we use to estimate the discontinuity have different implications to the relevant sample. The polynomial method uses all available data (all winners and all runners-up) to estimate the function and the discontinuity with power series of

\footnotetext{
${ }^{22}$ In Section 2 we discuss the ranking and the reason for not considering municipal councillor as a political victory.
} 
different degrees. We show the results with the polynomial method in the appendix. The local-averages method restricts the sample further. We compare winners and runners-up with a difference in vote share between them of less than $2 \%{ }^{23}$ For mayors, this implies comparing the winning mayor and the runner-up, so the $2 \%$ refers to the total vote for mayor in the municipality. In legislative and councillor elections, we compare candidates within a coalition: the worst ranked candidate that was elected receives the incumbency treatment and the best ranked candidate in the coalition who did not get elected is the control group. The $2 \%$ of the vote share refers to the total vote received by the coalition.

The unit of analysis is the individual candidate, but the inclusion of a winner and a runner-up in the RDD sample is determined by whether the election was close or not. By construction, the sample is perfectly balanced for all state and municipal characteristics; for legislative elections the sample is also balanced at the coalition level; and the density of the forcing variables will be identical on both sides of the cutoff. The balance tests to check the validity of the design must focus on politicians' characteristics: age, education, gender, marital status, and political party. We must check whether the average of each of these variables is not statistically different on both sides of the cutoff. There are missing values for some of these variables; an additional balance test is to check whether the number of missing variables is also similar on both sides of the cutoff. All balance tests are available in the Appendix.

In Table 3 we present the incumbency effects of being a federal legislator (elected

\footnotetext{
${ }^{23}$ We chose $2 \%$ because it is a sample restriction that can be implemented across offices. If we had chosen a smaller RDD sample, there would not be enough data to estimate the incumbency effects for federal legislators. All results with the $2 \%$ RDD samples are robust to different polynomial specifications. See Bueno et al. (2014) for a discussion on using local averages and polynomials for RDD.
} 
in year $t$ ) on the probabilities of winning a series of offices within 8 years ${ }^{24}$ The estimates of the reelection incumbency advantage are found in row 6 , where it can be seen that $43 \%$ if incumbents win reelection in $t+4$ and only $17 \%$ of runners-up from $t$ become federal legislators in $t+4$ (eight years after the election in $t$ we can see that a residual reelection incumbency advantage remains but it is not statistically significant). In rows 1 to 5 we can see the fraction of winners and runners-up in $t$ who win the election for other offices either in $t+2$ or in $t+4$. Note that runners-up are statistically more likely to become councillors two years later.

In row 7 we show the results for the multi-office incumbency advantage. Half of federal legislators who were bare winners in $t$ are able to win an important political office in $t+2$ or $t+4$; only $29 \%$ of runners-up do so. In row 10 we also include the possibility that winners in $t$ may wish to wait 6 years before attempting to run for a different office. The two estimates for multi-office incumbency advantage do not differ by much. The comparison between the reelection incumbency advantage in row 6 and the multi-office incumbency advantage in rows 7 or 10, show that a researcher who ignores the multi-office component in Brazilian politics may overestimate the true advantage gained from holding a seat in the Brazilian lower House.

Table 3 allows us to test the hypothesis that becoming a federal legislators is a stepping stone in the career of Brazilian politicians who wish to be mayors. In rows 2 and 9 we can see that a similar share of incumbent legislators (winners in $t$ ) and runners-up - approximately 7.5\% — manage to become mayors in the subsequent 6 years. We find no evidence of an across-office incumbency advantage from federal legislator to mayor. This results does not support the stepping-stone hypothesis proposed in Samuels (2003).

\footnotetext{
${ }^{24}$ In Table 3 we pool all electoral cycles. In the appendix Table 12 we present the results by electoral cycle. The estimates are similar across all electoral cycles for federal and state legislators.
} 
Table 3: Multi-Office Incumbency Advantage for Federal Legislators - 2\% window

\begin{tabular}{lcclc}
\hline \hline & \multicolumn{2}{c}{ mean } & Test Diff=0 & sample size \\
\hline & winner(t) & runner-up $(\mathrm{t})$ & $\mathrm{SE}$ & winner/runner-up \\
\hline Councillor t+2 years & 0 & 0.06 & $(0.02)^{* *}$ & $200 / 200$ \\
Mayor t+2 years & 0.06 & 0.09 & $(0.03)$ & $200 / 200$ \\
Senator t+4 years & 0.005 & 0.005 & $(0.007)$ & $200 / 200$ \\
Governor t+4 years & 0 & 0 & & $200 / 200$ \\
State legislator t+4 years & 0.03 & 0.02 & $(0.01)$ & $200 / 200$ \\
Federal legislator t+4 years & 0.43 & 0.17 & $(0.05)^{* * *}$ & $200 / 200$ \\
Multi-office success $(\mathrm{t}+4)$ & 0.5 & 0.29 & $(0.04)^{* * *}$ & $200 / 200$ \\
\hline Councillor t+6 years & 0.02 & 0.01 & $(0.01)$ & $146 / 146$ \\
Mayor t+6 years & 0.09 & 0.06 & $(0.02)$ & $146 / 146$ \\
Multi-office success $(\mathrm{t}+6)$ & 0.53 & 0.34 & $(0.04)^{* * *}$ & $146 / 146$ \\
\hline Senator t+8 years & 0.007 & 0.014 & $(0.012)$ & $146 / 146$ \\
Governor t+8 years & 0 & 0 & & $146 / 146$ \\
State legislator t+8 years & 0.02 & 0.04 & $(0.02)$ & $146 / 146$ \\
Federal legislator t+8 years & 0.19 & 0.11 & $(0.05)$ & $146 / 146$ \\
\hline \hline
\end{tabular}

Note: Samples consists of politicians from 1994, 1998, 2002, and 2006 who participated in an election for federal legislator and either won or were the runner up. Winner $(t)$ refers to candidates winning a seat with the lowest rank within a given coalition in year $t$ and runner-up $(t)$ refers to the highest ranking candidate within a coalition that lost a seat in year $t$. We restrict the sample to close elections: those in which the winner had a margin no greater than $2 \%$ of the total number of vote in the coalition. Winners and losers with tied votes are excluded. "Multi-office success $(t+4)$ " is defined as 1 if the candidate in $t$ wins either of the following posts within four years: mayor, senator, governor, state legislators, and federal legislator; and 0 otherwise. "Multioffice success $(\mathrm{t}+6)$ " extends the inclusion period to 6 years. For the periods where information is available we include vice-mayors as mayors, senator sup as senators, and vice-governors as governors. Standard Errors are clustered at the state level. ${ }^{*} p<0.1{ }^{* *} p<0.05{ }^{* * *} p<0.01$ 
In Table 4 we present the incumbency effects of being a state legislator (elected in year $t$ ) on the probabilities of winning a series of offices within 8 years. The estimates of the reelection incumbency advantage are found in row 6 , where it can be seen that $43 \%$ if incumbents win reelection in $t+4$ and $29 \%$ of runners-up from $t$ become state legislators in $t+4$. In rows 1 to 5 we can see the fraction of winners and runners-up in $t$ who win the election for other offices either in $t+2$ or in $t+4$. Note that runners-up are statistically more likely to become councillors and mayors two years later. In rows 7 and 10 we show the estimates for our two measures of multi-office incumbency advantage (i.e, $t+4$ and $t+6$ ). The reelection rate of incumbent is similar to that of federal legislators at approximately 50\%, but runners-up do better with $36 \%$ winning an office in the next 6 years (this $36 \%$ excludes the $7 \%$ if runners-up who become local councillors). Note in rows 5 and 11, that there is the suggestion of an across-office incumbency advantage from state to federal legislator. Bare winners are twice as likely to move upward to the federal legislature than runners-up either in $t+4$ or in $t+8$. However, the numbers are small, no more than $4 \%$ of the RDD sample, and the effect is not statistically significant.

In Table 5 we compare the electoral success across all offices in years $t+2$ to $t+8$ for bare winners and bare losers who ran for mayor in year $t$. In row 6 we report the estimate of the reelection measure of incumbency advantage. In rows 7 and 12 we report our measures of multi-office incumbency advantage. Our results suggest a small reelection incumbency advantage among Brazilian mayors, but no multi-office advantage. Note that $17 \%$ of the runners-up in $t$ are elected mayor in $t+8$, compared to $5 \%$ among winners in $t$. Of course, this incumbency disadvantage after 8 years is explained by a limit of two consecutive terms. Note also that we find no positive incumbency effect from being a mayor on the probability of moving into state or national political office. The average municipality in Brazil is small, so the 
Table 4: Multi-Office Incumbency Advantage for State Legislators - 2\% window

\begin{tabular}{lcclc}
\hline \hline \multicolumn{1}{c}{ Elected for: } & \multicolumn{2}{c}{ mean } & Test Diff=0 & sample size \\
\hline Councillor $\mathrm{t}+2$ years & 0 & 0.07 & $(0.01)^{* * *}$ & winner/runner-up \\
Mayor t+2 years & 0.03 & 0.05 & $(0.01)^{*}$ & $468 / 468$ \\
Senator $\mathrm{t}+4$ years & 0 & 0 & & $468 / 468$ \\
Governor $\mathrm{t}+4$ years & 0 & 0 & & $468 / 468$ \\
Federal legislator $\mathrm{t}+4$ years & 0.02 & 0.01 & $(0.01)$ & $468 / 468$ \\
State legislator $\mathrm{t}+4$ years & 0.43 & 0.29 & $(0.03)^{* * *}$ & $468 / 468$ \\
Multi-office success $(\mathrm{t}+4)$ & 0.47 & 0.35 & $(0.03)^{* * *}$ & $468 / 468$ \\
\hline Councillor $\mathrm{t}+6$ years & 0.01 & 0.06 & $(0.01)^{* * *}$ & $339 / 339$ \\
Mayor t+6 years & 0.06 & 0.05 & $(0.02)$ & $339 / 339$ \\
Multi-office success $(\mathrm{t}+6)$ & 0.51 & 0.36 & $(0.04)^{* * *}$ & $339 / 339$ \\
\hline Senator $\mathrm{t}+8$ years & 0 & 0 & & $339 / 339$ \\
Governor $\mathrm{t}+8$ years & 0 & 0 & & $339 / 339$ \\
Federal legislator $\mathrm{t}+8$ years & 0.04 & 0.02 & $(0.01)$ & $339 / 339$ \\
State legislator $\mathrm{t}+8$ years & 0.22 & 0.17 & $(0.04)$ & $339 / 339$ \\
\hline \hline
\end{tabular}

Note: Samples consists of politicians from 1994, 1998, 2002, and 2006 who participated in an election for state legislator and either won or were the runner up. Winner $(t)$ refers to candidates winning a seat with the lowest rank within a given coalition in year $t$ and runner-up $(t)$ refers to the highest ranking candidate within a coalition that lost a seat in year $t$. We restrict the sample to close elections: those in which the winner had a margin no greater than $2 \%$ of the total number of vote in the coalition. Winners and losers with tied votes are excluded. "Multi-office success $(t+4)$ " is defined as 1 if the candidate in $t$ wins either of the following posts within four years: mayor, senator, governor, state legislators, and federal legislator; and 0 otherwise. "Multioffice success $(\mathrm{t}+6)$ " extends the inclusion period to 6 years. For the periods where information is available we include vice-mayors as mayors, senator sup as senators, and vice-governors as governors. Standard Errors are clustered at the state level. ${ }^{*} p<0.1^{* *} p<0.05^{* * *} p<0.01$ 
average politician is unlikely to have the necessary resources and vote base to move on to the state or national stage. Surprisingly, we also find that mayors are very unlikely to become local councillors. Actually, being the runner-up slightly increases the probability of becoming a local councillor, but the numbers are small: less than $3 \%$. This small rate of transition from mayors into other offices - which can also be seen in Table 2 - implies that the measures of reelection incumbency advantage and multi-office incumbency advantage are almost identical. For mayoral elections, the focus on the reelection incumbency advantage in Brazil is justified. This is also the case for elections for councillor, which we discuss in Section 3.3 .

For all three offices we study in this section (i.e., mayors, state, and federal legislators) we find a clear causal effect that runners-up are more likely to win an election for local council subsequently. This suggests that the office of local councillor may be seen as a safety net post not only for mayors, but also for state and federal legislators. Politicians who are good enough to be a runner-up and wish to stay alive in politics, tend to go for the post of local councillor. This is an interesting phenomenon as it shows how closely related are local, state, and national politics in Brazil.

\subsection{Revolving-doors Municipalities}

In this section we focus on the politically influential municipalities in Brazil. Being a mayor of these municipalities may be seen as an important state or national political post (e.g., being the mayor of the state's largest city). We let the data determine the specific sample, i.e., we restrict the sample to the municipalities where there were

— during the period covered by our sample - at least 1 politician who held both a local office and a federal or state office. We call these municipalities "revolving-door" 
Table 5: Multi-Office Incumbency Advantage for Mayors - 2\% window

\begin{tabular}{lcccc}
\hline \multicolumn{1}{c}{ Elected for: } & winner(t) & runner-up $(\mathrm{t})$ & $\mathrm{SE}$ & winner/runner-up \\
\hline State legislator $\mathrm{t}+2$ years & 0 & 0.014 & $(0.003)^{* * *}$ & $1384 / 1384$ \\
Federal legislator $\mathrm{t}+2$ years & 0 & 0.004 & $(0.002)^{* *}$ & $1384 / 1384$ \\
Senator $\mathrm{t}+2$ years & 0 & 0.001 & $(0.001)$ & $1384 / 1384$ \\
Governor $\mathrm{t}+2$ years & 0 & 0 & & $1384 / 1384$ \\
Councillor $\mathrm{t}+4$ years & 0.001 & 0.02 & $(0.004)^{* * *}$ & $1384 / 1384$ \\
Mayor $\mathrm{t}+4$ years & 0.34 & 0.30 & $(0.021)^{* *}$ & $1384 / 1384$ \\
Multi-office success $(\mathrm{t}+4)$ & 0.34 & 0.31 & $(0.021)$ & $1384 / 1384$ \\
\hline State legislator $\mathrm{t}+6$ years & 0 & 0.005 & $(0.002)^{* *}$ & $935 / 935$ \\
Federal legislator $\mathrm{t}+6$ years & 0.001 & 0.001 & $(0.002)$ & $935 / 935$ \\
Senator $\mathrm{t}+6$ years & 0 & 0 & & $935 / 935$ \\
Governor $\mathrm{t}+6$ years & 0 & 0 & & $935 / 935$ \\
Multi-office success $(\mathrm{t}+6)$ & 0.34 & 0.31 & $(0.021)$ & $935 / 935$ \\
\hline Councillor $\mathrm{t}+8$ years & 0.012 & 0.023 & $(0.006)$ & $935 / 935$ \\
Mayor $\mathrm{t}+8$ years & 0.05 & 0.17 & $(0.015)^{* * *}$ & $935 / 935$ \\
\hline \hline
\end{tabular}

Note: This sample comprises politicians who participated in Mayoral elections in 1996, 2000 and 2004. We include vice-mayors as mayors, senator sup as senators, and vice-governors as governors. We restrict the sample to close elections: those in which the winner had a margin no greater than $2 \%$ of the total number of vote in the municipality. Standard Errors are clustered at the municipality level. ${ }^{*} p<0.1^{* *} p<$ $0.05^{* * *} p<0.01$ 
municipalities. The characteristics of these municipalities can be seen in Table6. In column 1 we present the average characteristics of municipalities where no local politician ever won a state of federal office. In column 2 we restrict the sample to revolving-door municipalities. In column 3, we present the characteristics of the average municipality. Revolving-door municipalities are at least six times larger than the average municipality in terms of population, approximately $20 \%$ richer, and slightly more concentrated in the Norther region.

Table 6: Characteristics of Municipalities where Legislators become Mayors and vice-versa

\begin{tabular}{lccc}
\hline & No Legislator & Revolving-door & All Municipalities \\
\hline Population mean & 20778 & 422060 & 52325 \\
Population median & 11255 & 122701 & 12365 \\
Income per capita mean & 5655 & 7097 & 5769 \\
Income per capita median & 3811 & 5586 & 4005 \\
South & 0.21 & 0.17 & 0.21 \\
South-East & 0.3 & 0.29 & 0.3 \\
Center-West & 0.08 & 0.09 & 0.08 \\
North-East & 0.32 & 0.29 & 0.32 \\
North & 0.08 & 0.15 & 0.08 \\
number of obs. & 5476 & 330 & 5561 \\
\hline \hline
\end{tabular}

Note: Revolving-door municipalities are defined as municipalities from where a mayor became state or federal legislator, or previous state or federal legislator became a mayor in the municipality The income and population data for these municipalities comes from 2002 census.

In Table 7 we present the political transitions for mayors and runners-up in the revolving-door municipalities. These results are not from a RDD; they are estimates with all winners and all runners-up, independent on their vote share. In rows 1 and 
2 we can observe the midterm effect that allows the runners-up to run for state or federal legislator 2 years after a defeat, $18 \%$ of runners-up become legislators in $t+2$. In row 6 we can see that $47 \%$ of mayors gain reelection and only $11 \%$ of runnersup do so, and in rows 1 and 2 it can be seen that virtually no incumbent mayor leaves their office in the middle of their term in order to become either a state or federal legislator. But in $t+6$ approximately $10 \%$ of incumbent mayors become state legislators.

In Table 8 we estimate - with a RDD - the multi-office incumbency effects for mayors in the revolving-door municipalities. The runner-up advantage when running for state or federal legislative office makes the multi-office advantage of mayors considerably smaller than their reelection advantage (and statistically indistinguishable). In row 6 we have the estimates of the reelection incumbency advantage: $52 \%$ of incumbents win reelection for mayor and only $21 \%$ of runners-up manage to become mayors in four years later. However, in rows 1 and 2 we can see that while no incumbent mayors wins a state or federal office, $13 \%$ and $7 \%$ of runners-up win, respectively, state and federal legislative offices. This results are robust to including elections within 6 years and are also robust to the estimation with polynomials (see the appendix Table 21).

The results in this section lends support to the categorization of politician ideal types proposed in Samuels (2003). In particular, the results in Table 7 and Table 8 support the presence of "municipal-directed" politicians (i.e., runners-up), who become legislators in order to stay alive in politics until they can pursue their goal of becoming mayor. This result combined with the results in the previous section, however, suggest that the "municipal-directed" politicians can only exist in the sample of revolving-door municipalities. The average municipality is too small and neither incumbents nor runners-up are able to transit into state or federal politics from the 
average municipality.

In summary, the estimates of multi-office incumbency advantage for Brazil shows us that there is a very segmented market separating local from state/federal politics with the exception of the revolving-door municipalities. No local politician transits successfully into state of federal politics outside these 330 municipalities. Within the revolving-door municipalities our results suggest that being a mayor is an end on itself, as we find no positive incumbency effect on the probability of becoming a state or federal legislators. Instead, it seems that successful politicians (i.e., either incumbents or close runners-up ) alternate between being mayor and holding state or federal legislative office. Among the mayors in the other municipalities and among legislators, reelection seems to be the main objective. The result discussed in this section and in Table 2 are supported by Table 22 in the appendix, where we present a transition matrix of where current office holds chose to run next: more than $60 \%$ of mayors, state, and federal legislators run for reelection; only $16 \%$ of legislators run for mayor, and these include those that run within two years (which implies that they can run for reelection while keeping their legislative office). 
Table 7: Political Career of Mayors in Revolving-door Municipalities

\begin{tabular}{lcclc}
\hline \hline & \multicolumn{2}{c}{ mean } & Test Diff=0 & All Sample \\
\hline \multicolumn{1}{c}{ Elected for: } & winner $(\mathrm{t})$ & runner-up(t) & $\mathrm{SE}$ & winner/runner-up \\
\hline State legislator $\mathrm{t}+2$ years & 0.006 & 0.12 & $(0.014)^{* * *}$ & $656 / 656$ \\
Federal legislator $\mathrm{t}+2$ years & 0 & 0.06 & $(0.009)^{* * *}$ & $656 / 656$ \\
Senator t+2 years & 0 & 0.003 & $(0.002)$ & $656 / 656$ \\
Governor t+2 years & 0.003 & 0 & $(0.002)$ & $656 / 656$ \\
Councillor t+4 years & 0.002 & 0.044 & $(0.008)^{* * *}$ & $656 / 656$ \\
Mayor t+4 years & 0.47 & 0.117 & $(0.026)^{* * *}$ & $656 / 656$ \\
Multi-office success $(\mathrm{t}+4)$ & 0.48 & 0.28 & $(0.026)^{* * *}$ & $656 / 656$ \\
\hline State legislator $\mathrm{t}+6$ years & 0.104 & 0.047 & $(0.016)^{* * *}$ & $450 / 450$ \\
Federal legislator $\mathrm{t}+6$ years & 0.024 & 0.033 & $(0.011)$ & $450 / 450$ \\
Senator t+6 years & 0 & 0.002 & $(0.002)$ & $450 / 450$ \\
Governor t+6 years & 0.007 & 0.004 & $(0.005)$ & $450 / 450$ \\
Multi-office success $(\mathrm{t}+6)$ & 0.55 & 0.29 & $(0.028)^{* * *}$ & $450 / 450$ \\
Councillor Election $\mathrm{t}+8$ years & 0.011 & 0.036 & $(0.01)^{* *}$ & $450 / 450$ \\
Mayor t+8 years & 0.022 & 0.118 & $(0.017)^{* * *}$ & $450 / 450$ \\
\hline \hline
\end{tabular}

Note: Samples consist of politicians from 1996, from 2000, and from 2004 in the 330 municipalities where a local politician also held a state or federal elected office. It includes candidates who participated in a mayoral election in year $t$ and either won or were the runner up. We restrict the sample to close elections: those in which the winner had a margin no greater than $2 \%$ of the total number of vote in the municipality. For the 2000 and 2004 mayoral elections we exclude municipalities where the winning mayor faces a term limit four years later. Standard Errors are clustered at the municipality level. ${ }^{*} p<0.1^{* *} p<0.05^{* * *} p<0.01$ 
Table 8: Multi-Office Incumbency Advantage for Mayors - Revolving-door Municipalities - $2 \%$ window

\begin{tabular}{|c|c|c|c|c|}
\hline & \multicolumn{2}{|c|}{ mean } & Test Diff $=0$ & RDD sample $-2 \%$ window \\
\hline Elected for: & winner $(\mathrm{t})$ & runner-up $(\mathrm{t})$ & $\mathrm{SE}$ & winner/runner-up \\
\hline State legislator $t+2$ years & 0 & 0.13 & $(0.045)^{* * *}$ & $56 / 56$ \\
\hline Federal legislator $t+2$ years & 0 & 0.07 & $(0.035)^{* *}$ & $56 / 56$ \\
\hline Senator $t+2$ years & 0 & 0 & & $56 / 56$ \\
\hline Governor $t+2$ years & 0 & 0 & & $56 / 56$ \\
\hline Councillor $\mathrm{t}+4$ years & 0 & 0 & & $56 / 56$ \\
\hline Mayor $\mathrm{t}+4$ years & 0.52 & 0.21 & $(0.108)^{* * *}$ & $56 / 56$ \\
\hline Multi-office success $(t+4)$ & 0.52 & 0.41 & $(0.091)$ & $56 / 56$ \\
\hline State legislator $\mathrm{t}+6$ years & 0 & 0 & & $37 / 37$ \\
\hline Federal legislator $\mathrm{t}+6$ years & 0 & 0 & & $37 / 37$ \\
\hline Senator $\mathrm{t}+6$ years & 0 & 0 & & $37 / 37$ \\
\hline Governor $\mathrm{t}+6$ years & 0 & 0 & & $37 / 37$ \\
\hline Multi-office success $(t+6)$ & 0.52 & 0.41 & $(0.093)$ & $37 / 37$ \\
\hline Councillor Election $t+8$ years & 0 & 0 & & $37 / 37$ \\
\hline Mayor $\mathrm{t}+8$ years & 0.14 & 0.11 & $(0.065)$ & $37 / 37$ \\
\hline
\end{tabular}

Note: Samples consist of politicians from 1996, from 2000, and from 2004 who participated in a Mayoral election in that year and either Won or were the runner up. This sample comprises politicians who participated in Mayoral elections in 1996, 2000 and 2004. We restrict the sample to close elections: those in which the winner had a margin no greater than $2 \%$ of the total number of vote in the munincipality. Standard Errors are clustered at the munincipality level. ${ }^{*} p<0.1^{* *} p<0.05^{* * *} p<0.01$ 


\subsection{Incumbency Advantage Over Time}

So far we have show results in which we have pooled all electoral cycles 25 Pooling the results provides a clear summary and it is a valid exercise for most offices. In the appendix Table 12, we show that both the multi-office and reelection incumbency advantage results have similar estimates in each electoral cycle for local councillor, state, and federal legislators.

In this section we focus on mayoral elections over time. The focus on local elections implies that reelection or multi-office incumbency advantage yield almost identical results. In Table 9 we show that the estimated incumbency advantage for mayors moves considerably over time. There is no incumbency advantage or disadvantage in the 1996-2000 electoral cycle: ${ }^{26}$ There is a suggestion of an incumbency disadvantage in the 2000-2004 electoral cycle which we discuss in detail next. In the 2004-2008 electoral cycle there is a clear incumbency advantage for mayors. Note that these change can be identified with time effects as the sample of municipalities with close elections has similar characteristics in all three electoral cycles (see the on-line appendix Table 27) 27

The data suggests an incumbency disadvantage among mayors elected in 2000.

\footnotetext{
${ }^{25}$ Showing the results by electoral cycle — as has been noted in Sekhon and Titiunik $(2012)$ is necessary to demonstrate the validity of the RDD results.

${ }^{26}$ A law that allowed mayors to seek reelection for one extra term was approved in 1997 . All mayors elected in 1996 were allowed to seek reelection in 2000. From 2000 onwards we must restrict the analysis to municipalities where the term limit is not binding. For example, the baseline sample for the analysis of the 2000-2004 electoral cycle is 5522 municipalities. Once we exclude the municipalities where the incumbent mayor faces a term limit in 2004, the sample drops to 3553 municipalities.

${ }^{27}$ Were this not the case, then the different results for different electoral cycles could be driven by different municipality characteristics.
} 
Table 9: Municipal Incumbency Advantage: local averages - RDD sample - 2\%

\begin{tabular}{|c|c|c|c|c|}
\hline & \multicolumn{2}{|c|}{ mean } & Test Diff $=0$ & sample size \\
\hline Elected in $(t+4)$ for: & winner $(\mathrm{t})$ & runner-up (t) & $\mathrm{SE}$ & winner/runner-up \\
\hline Mayor in 2000 & 0.29 & 0.27 & $(0.03)$ & $551 / 551$ \\
\hline Mayor in 2004 & 0.31 & 0.37 & $(0.02)$ & $385 / 385$ \\
\hline Mayor in 2008 & 0.41 & 0.27 & $(0.04)^{* * *}$ & $488 / 488$ \\
\hline
\end{tabular}

Note: This sample comprises the politicians who participated in elections from 1994 to 2010 . The sample is restricted to winners and runners-up with a vote difference of $2 \%$. Standard errors are clustered at the municipality level. ${ }^{*} p \leq .10,{ }^{* *} p \leq .05$, ${ }^{* * *} p \leq .01$.

In fact, the polynomial estimates in the appendix (Table 16) show a statistically significant incumbency disadvantage for the 2000-2004 electoral cycle for mayors. To try and understand the possible mechanism, we break down the 2000-2004 electoral cycle in Table 10. We look separately at municipalities where i) the winner and the runner-up in 2000 belonged to the PSDB-led coalition ${ }^{28}$ ii) the winner belonged to the coalition but not the runner-up, and iii) the runner-up belonged to the coalition but not the winner ${ }^{29}$ The incumbency estimates for the other electoral cycles are robust to this break down (i.e., the estimates have the same sign for each group of municipalities).

We propose such a split in the data because in 2002 the PSDB-led coalition lost the Brazilian presidency to the opposition candidate from the PT (Lula) ${ }^{30}$ Mayors who belonged to parties in the PSDB presidential coalition lost support from the central government when the time came to seek reelection. The new presidential

\footnotetext{
${ }^{28}$ PSDB stands for Partido Social-Democrata do Brasil and it is Brazil's main center-right party.

${ }^{29}$ The number of municipalities where neither belonged to the coalitions is negligible.

${ }^{30} \mathrm{PT}$ stands for Partido dos Trabalhadores and it is Brazil's main center-left party.
} 
coalition led by the PT may have been able to influence these close elections through mechanisms such as coattail effects from Lula's popularity or the lost capacity for the parties in the PSDB coalition to raise campaign money. The mostly likely mechanism, however, seems to be the one suggested by Brollo and Nannicini (2012). Their evidence suggests that the federal government is able to starve of funds the municipalities where the incumbent belongs to the opposition. This implies that the central government is able to hinder sitting mayors, and this is what we observe 31

In Table 10 we can see that the incumbency disadvantage is entirely driven by races where the winner in 2000 was part of the PSDB-led coalitions and the runner-up was part of the opposition led by the PT. In these municipalities, $55 \%$ of runnersup won the election for mayor in 2004, whereas only $21 \%$ of the incumbents won reelection. There is no incumbency disadvantage in the municipalities where both incumbents and runners-up belonged to the PSDB-led coalition, which represent more than $70 \%$ of all municipalities. The mechanism suggested by Brollo and Nannicini (2012) is the one that is more likely to drive the result. If there was positive coattail effect of Lula across the country, we would expect that winning mayors in $t$ who were in the opposition (did not belong to the PSDB-led coalition) to have an easier time being reelected. But this is not the case as can be seen in the last row of Table 10. In the appendix Table 10 and 14 we show that the results for the other electoral cycles are robust to the municipalities being partitioned by type of electoral race.

The results in this section of the paper relate to a large literature on Brazilian mayoral elections: Ferraz and Finan (2008), Ferraz and Finan (2011), Brollo et al. (2013), and Brollo and Nannicini (2012). These paper have looked at whether

\footnotetext{
${ }^{31}$ This interference of the central government onto municipal politics is no surprise as Ames (1994) shows that mayors are able to influence presidential elections.
} 
corruption, access to information, or federal transfers affect the electoral outcomes in Brazilian mayoral elections. None of these papers, however, have asked what is the benchmark incumbency advantage (or disadvantage) across time for Brazilian mayors. This is what we report in Table 9 .

Table 10: Presidential coattails effect in the 2004 Mayoral election - RDD sample local averages

\begin{tabular}{lcclc}
\hline \hline \multicolumn{1}{c}{ Sample } & winner & runner-up & SE & winner $/$ runner-up \\
\hline $\begin{array}{l}\text { All winners } \\
\text { and runners-up }\end{array}$ & 0.31 & 0.37 & $(0.02)$ & $385 / 385$ \\
\hline $\begin{array}{l}\text { Winner and runner-up in } \\
\text { 2000 PSDB coalition }\end{array}$ & 0.33 & 0.33 & $(0.05)$ & $229 / 229$ \\
\hline $\begin{array}{l}\text { Winner in coalition } \\
\text { Runner-up not in coalition }\end{array}$ & 0.21 & 0.51 & $(0.10)^{* * *}$ & $66 / 66$ \\
\hline $\begin{array}{l}\text { Winner not in coalition } \\
\text { Runner-up in coalition }\end{array}$ & 0.35 & 0.37 & $(0.09)$ & $83 / 83$ \\
\hline
\end{tabular}

Note: This sample comprises 770 politicians who participated in the 2000 mayoral election and either won or were the runner up. Row 1 restricts the sample to the 229 municipalities where both the winner and the runner-up in the 2000 election were from parties belonging to the President's ruling coalition: PMDB, PFL, PSDB, PP, PTB, or PPS. Row 2 restricts the sample to the 66 municipalities where the winner in the 2000 election was from parties in the coalition and the runner-up was from opposition parties. Row 3 restricts the sample to 83 municipalities where the runner-up in the 2000 election was from a party in the President's ruling coalition but the winner was not. Standard errors are clustered at the municipality level. ${ }^{*} p \leq .10,{ }^{* *} p \leq .05$, ${ }^{* * *} p \leq .01$. 


\section{Final Remarks}

The main general interest contribution of this paper is to expand the concept of incumbency advantage to across-office incumbency advantage and to multi-office incumbency advantage. If there were a high number of incumbents who sought to be elected for other offices, the models used to understand such political systems would have to take that into account. Politicians may not be maximizing their probability of reelection, but their probability of switching to a particular office, or simply holding any office. Decisions made by such a politician may be misinterpreted if one imposes the usual model that focus on reelection as the main objective. Moreover, models that assume purely reelection incentives have been used to explain the development of institutions in the American Congress (Katz and Sala (1996)). Acknowledging that in other political system reelection incentives for the same office may not be as strong may help us understand differential institutional development.

Whether these across-office and multi-office election incentives are relevant or not is an empirical question. A further contribution of this paper is to use a novel Brazilian dataset, which tracks all politicians who ever ran for office from 1994 to 2010, in order to estimate across-office and multi-office incumbency advantage. These results are a contribution to the study of comparative politics and in particular of Brazil. We find that the runners-up for legislative office do quiet well in being elected for other offices in Brazil. This implies that the estimates of reelection incumbency advantage are an overestimate of the true incumbency advantage to one's career of holding a particular office.

Finally, we are able to test some hypotheses regarding the Brazilian political system. First - in contrast to previous work - we shoe there is no reelection incumbency disadvantage in Brazil. Instead, we show a clear and strong reelection 
incumbency advantage for state and federal legislators. For mayors there seems to be a weak advantage. Second, we test the hypothesis by Samuels (2003) that the office of legislator may be used as a stepping stone to becoming a mayor. We find that holding the office of legislator (state or federal) has no causal effect on the probability of becoming a mayor. Third, we do find support for the categorization of Brazilian political types suggested by Samuels (2003). By focusing on a subsample of revolving-door municipalities we show that it is the runners-up to the mayoral election who go on to become legislators two years later. The legislative offices are used by the runners-up as a way to 'stay alive' until they may try for mayor again. 


\section{References}

Ames, B. (1994). The Reverse Coattails Effect: Local Party Organization in the 1989 Brazilian Presidential Election. American Political Science Review, 88(01):95-111.

Ames, B. (1995). Electoral Stategy under Open-List Proportional Representation. American Journal of Political Science, 39(2):406-433.

Ansolabehere, S., Snyder, J., and Stewart, C. (2000). Old Voters, New Voters, and the Personal Vote: Using Redistricting to Measure the Incumbency Advantage. American Journal of Political Science, 44(1):17-34.

Brambor, T. and Ceneviva, R. (2011). Incumbency Advantage in Brazilian Mayoral Elections. Working Paper.

Brollo, F. and Nannicini, T. (2012). Tying Your Enemy's Hands in Close Races: The Politics of Federal Transfers in Brazil. American Political Science Review.

Brollo, F., Nannicini, T., Perotti, R., and Tabellini, G. (2013). The Political Resource Curse. American Economic Review, 103(5):1759-96.

Bueno, N., Dunning, T., and Tuñón, G. (2014). Design-Based Analysis of Regression Discontinuities: Evidence from an Experimental Benchmark. Presented at APSA in Washington DC.

Cox, G. W. and Katz, J. N. (1996). Why did the Incumbency Advantage in U.S. House Elections Grow? American Journal of Political Science, 40(2):478-497.

Cunow, S., Ames, B., Desposato, S., and Renno, L. (2012). Reelection and Legislative Power: Surprising Results from Brazil. Legislative Studies Quarterly, 37(4):533558. 
De Magalhães, L. (2015). Incumbency Effects in a Comparative Perspective: Evidence from Brazilian Mayoral Elections. Political Analysis, 23(1):113-126.

Diermeier, D., Keane, M., and Merlo, A. (2005). A Political Model of Congressional Careers. The American Economic Review, 95(1):347-373.

Eggers, A., Fowler, A., Hainmueller, J., Hall, A. B., and Snyder, J. M. (2015). On the Validity of the Regression Discontinuity Design for Estimating Electoral Effects: Evidence From Over 40,000 Close Races. American Journal of Political Science, $59(1): 259-274$.

Eggers, A. C. and Spirling, A. (2014). A Framework for Interpreting Party Incumbency Effects: With Application to the United Kingdom, 1833-2001. mimeo Oxford.

Epstein, D., Brady, D., Kawato, S., and O'Halloran, S. (1997). A Comparative Approach to Legislative Organization: Careerism and Seniority in the United States and Japan. American Journal of Political Science, pages 965-998.

Erikson, Robert, S. (1971). The Advantage of Incumbency in Congressional Elections. Polity, 3(3):395-405.

Ferraz, C. and Finan, F. (2008). Exposing Corrupt Politicians: The Effects of Brazil's Publicly Released Audits on Electoral Outcomes. Quarterly Journal of Economics.

Ferraz, C. and Finan, F. (2011). Electoral Accountability and Corruption: Evidence from the Audits of Local Governments. American Economic Review, 101:12741311. 
Fowler, A. and Hall, A. B. (2014). Disentangling the Personal and Partisan Incumbency Advantages: Evidence from Close Elections and Term Limits. Quaterly Journal of Political Science, 9:501-531.

Gelman, A. and King, G. (1990). Estimating Incumbency Advantage without Bias. American Journal of Political Science, 34(4):1142-1164.

Hall, R. L. and Van Houweling, R. P. (1995). Avarice and Ambition in Congress: Representatives' Decisions to Run or Retire from the US House. American Political Science Review, 89(01):121-136.

Herrick, R. and Nixon, D. L. (1996). Is There Life After Congress? Patterns and Determinants of Post-Congressional Careers. Legislative Studies Quarterly, pages 489-499.

Katz, J. N. and Sala, B. R. (1996). Careerism, Committee Assignments, and the Electoral Connection. American Political Science Review, 90(01):21-33.

Klašnja, M. and Titiunik, R. (2013). Incumbency Disadvantage In Weak Party Systems: Evidence from Brazil. Unpublished manuscript, University of Michigan.

Lee, D. S. (2001). The Electoral Advantages To Incumbency and Voters' Valuation of Politicians' Experience: A Regression Discontinuity Analysis of Elections to the U.S. House. Working Paper NBER 8441.

Lee, D. S. (2008). Randomized Experiments from Non-random Selection in U.S. House Elections. Journal of Econometrics, 142:675-697.

Leoni, E., Pereira, C., and Rennó, L. (2004). Political Survival Strategies: Political Career Decisions in the Brazilian Chamber of Deputies. Journal of Latin America Studies, 36:109-130. 
Levitt, S. D. and Wolfram, C. D. (1997). Decomposing the Sources of Incumbency Advantage in the U.S. House. Legislative Studues Quarterly, 22(1):45-60.

Linden, L. L. (2004). Are Incumbents Advantaged? The Preference for NonIncumbents in Indian National Elections. MIT Working Paper.

Mayhew, D. R. (1974). Congress: The Electoral Connection. Yale University Press. Pereira, C. and Renno, L. (2003). Successful Re-election Strategies in Brazil: The Electoral Impact of Distinct Institutional Incentives. Electoral Studies, 22(3):425448.

Pereira, C. and Rennó, L. (2004). 'Should I Stay or Should I Go?' Explaining Political Ambition by Electoral Sucess in Brazil. Journal of Latin America Studies, 36:109-130.

Rohde, D. (1979). Risk-Bearing and Progressive Ambition: The Case of Members of the United States House of Representatives. American Journal of Political Science, $23(1): 1-26$.

Samuels, D. J. (2003). Ambition, Federalism, and Legislative Politics in Brazil. Cambridge University Press.

Schlesinger, J. A. (1966). Ambition and Politics: Political Careers in the United States. Chicago University Press.

Sekhon, J. S. and Titiunik, R. (2012). When Natural Experiments are neither Natural nor Experiments. American Political Science Review, 106(1):35-57.

Uppal, Y. (2008). The Disadvantaged Incumbents: Estimating Incumbency Effects in Indian State Legislatures. Public Choice, 138(1-2):9-27. 


\section{A APPENDIX}

Table 11: Summary Statistics of Number of Observations

\begin{tabular}{|c|c|c|c|c|c|c|c|c|c|}
\hline To: & 1994 & 1996 & 1998 & 2000 & 2002 & 2004 & 2006 & 2008 & 2010 \\
\hline Councillor with result & & 307134 & & 365589 & & 344437 & & 330242 & \\
\hline Councillor result missing & & 203 & & 2104 & & 1845 & & 18217 & \\
\hline Mayor with result & & 15350 & & 14947 & & 15546 & & 15359 & \\
\hline Mayor result missing & & 9 & & 86 & & 192 & & 207 & \\
\hline Vice-Mayor with result & & 0 & & 0 & & 15520 & & 15071 & \\
\hline Vice-Mayor result missing & & 445 & & 15013 & & 208 & & 326 & \\
\hline State Deputy with result & 7963 & & 9939 & & 11121 & & 10081 & & 10813 \\
\hline State Deputy result missing & 41 & & 113 & & 224 & & 100 & & 87 \\
\hline Federal Deputy with result & 3008 & & 3357 & & 4197 & & 4239 & & 4418 \\
\hline Federal Deputy result missing & 29 & & 60 & & 100 & & 45 & & 31 \\
\hline Senator with result & 232 & & 164 & & 307 & & 191 & & 180 \\
\hline Senator result missing & 0 & & 5 & & 12 & & 2 & & 5 \\
\hline Sup. Senator with result & 0 & & 0 & & 302 & & 191 & & 177 \\
\hline Sup. Senator result missing & 443 & & 162 & & 8 & & 5 & & 105 \\
\hline Governor with result & 134 & & 148 & & 194 & & 167 & & 130 \\
\hline Governor result missing & 0 & & 3 & & 8 & & 21 & & 1 \\
\hline Vice Governor with result & 0 & & 0 & & 194 & & 166 & & 130 \\
\hline Vice Governor result missing & 134 & & 149 & & 7 & & 22 & & 41 \\
\hline
\end{tabular}


Table 12: Incumbency Advantage in Brazil over time: local averages - RDD sample $-2 \%$

\begin{tabular}{lllll}
\hline \hline & mean & Test Diff=0 & sample size \\
\hline Elected in $(\mathrm{t}+4)$ for: & winner $(\mathrm{t})$ & runner-up $(\mathrm{t})$ & $\mathrm{SE}$ & winner $/$ runner-up \\
\hline
\end{tabular}

\section{State Legislator}

Reelected in 1998

Multi-office success $(1994+6)$

0.48

0.30

$(0.09)^{*}$

$56 / 56$

Reelected in 2002

0.55

0.41

$56 / 56$

Multi-office success $(1998+6)$

0.38

0.24

$(0.04)^{* * *}$

$140 / 140$

Reelected in in 2006

0.44

0.33

$(0.06)^{*}$

$140 / 140$

Reelected in in 2006

0.46

0.29

$(0.07)^{* *}$

$143 / 143$

Multi-office success $(2002+6)$

0.56

0.37

$(0.06)^{* * *}$

$143 / 143$

Reelected in in 2010

0.43

0.33

(0.06)

$129 / 129$

Multi-office success $(2006+4)$

0.45

0.37

$(0.06)$

$129 / 129$

\section{Federal Legislator}

Reelected in 1998

0.46

0.24

$(0.1)^{*}$

$33 / 33$

Multi-office success (1994+6)

0.52

0.46

(0.13)

$33 / 33$

Reelected in 2002

0.51

0.28

$(0.1)^{* *}$

$51 / 51$

Multi-office success (1998+6)

0.69

0.37

$(0.1)^{* * *}$

$51 / 51$

Reelected in 2006

0.32

0.16

$(0.08) * *$

$62 / 62$

Multi-office success $(2002+6)$

0.4

0.26

$(0.08) * *$

$62 / 62$

Reelected in 2010

0.44

0.04

$(0.07)^{* * *}$

$54 / 54$

Multi-office success $(2006+4)$

0.46

0.17

$(0.09)^{* * *}$

$54 / 54$

\section{Local Councillor}

Reelected in 2004

0.26

0.24

$(0.006)^{* * *}$

$11314 / 11314$

Reelected in 2008

0.32

0.28

$(0.007)^{* * *}$

10120/10120

Note: This sample comprises the politicians who participated in elections from 1994 to 2010. The sample is restricted to wint2rs and runners-up with a vote difference $2 \%$ the coalition level. Standard errors are clustered at the state level for legislative elections and at the municipal level for local councillor elections. ${ }^{*} p \leq .10,{ }^{* *} p \leq .05$, ${ }^{* * *} p \leq .01$. 
Table 13: Winners and runners-up from the 1996 election - local averages - regression discontinuity sample: $2 \%$ window

\begin{tabular}{lccccc}
\hline \hline & \multicolumn{2}{c}{ Elected Mayor in 2000 } & Test Diff=0 & \multicolumn{2}{c}{ sample size } \\
\hline \multicolumn{1}{c}{ Sample restriction } & winner & runner-up & SE & winner & runner-up \\
\hline $\begin{array}{l}\text { Winner and runner-up in } \\
\text { Presidential coalition }\end{array}$ & 0.31 & 0.28 & $(0.03)$ & 315 & 315 \\
\hline $\begin{array}{l}\text { Winner in coalition } \\
\text { Runner-up not in coalition }\end{array}$ & 0.24 & 0.33 & $(0.04)$ & 107 & 107 \\
\hline $\begin{array}{l}\text { Winner not in coalition } \\
\text { Runner-up in coalition }\end{array}$ & 0.27 & 0.21 & $(0.05)$ & 107 & 107 \\
\hline $\begin{array}{l}\text { Winner not in coalition } \\
\text { Runner-up not in coalition }\end{array}$ & 0.27 & 0.18 & $(0.15)$ & 22 & 22 \\
\hline \hline
\end{tabular}

Note: This sample comprises 1102 politicians who participated in the 1996 mayoral election and either won or were the runner up. Row 1 restricts the sample to the 315 municipalities where both the winner and the runner-up in the 1996 election were from parties belonging to the President's ruling coalition: PMDB, PFL, PSDB, PP, PTB, or PPS. Row 2 restricts the sample to the 107 municipalities where the winner in the 1996 election was from parties in the coalition and the runner-up was from opposition parties. Row 3 restricts the sample to 107 municipalities where the winner was not from a party in the Presidential coalition but where the runner-up was. Standard errors are clustered at the municipality level. Row 4 restricts the sample to 44 municipalities where both the winner and the runner-up were not from a party in the Presidential coalition. Standard errors are clustered at the municipality level. ${ }^{*} p \leq .10,{ }^{* *} p \leq .05,{ }^{* * *} p \leq .01$. 
Table 14: Winners and runners-up from the 2004 election - 2\% window - local averages

\begin{tabular}{lccccc}
\hline \hline & \multicolumn{2}{c}{ Proportion elected in 2008 } & Test Diff=0 & \multicolumn{2}{c}{ sample size } \\
\hline \multicolumn{1}{c}{ Sample restriction } & winner & runner-up & SE & winner & runner-up \\
\hline $\begin{array}{l}\text { Winner and runner-up in } \\
\text { Presidential coalition }\end{array}$ & 0.44 & 0.19 & $(0.08)^{* * *}$ & 86 & 86 \\
\hline $\begin{array}{l}\text { Winner in coalition } \\
\text { Runner-up not in coalition }\end{array}$ & 0.43 & 0.27 & $(0.07)^{* *}$ & 130 & 130 \\
\hline $\begin{array}{l}\text { Winner not coalition } \\
\text { Runner-up in coalition }\end{array}$ & 0.41 & 0.28 & $(0.07)^{*}$ & 134 & 134 \\
\hline $\begin{array}{l}\text { Winner not coalition } \\
\text { Runner-up not in coalition }\end{array}$ & 0.37 & 0.32 & & & 100 \\
\hline \hline
\end{tabular}

Note: This sample comprises 900 politicians who participated in the 2004 mayoral election and either won or were the runner up. The sample excludes municipalities where the term limit was binding in 2004. Row 1 restricts the sample to the 86 municipalities where both the winner and the runner-up in the 2004 election were from parties belonging to the President's ruling coalition: PT, PMDB, PSB, PDT, PL, PTB, PV, PC do B. Row 2 restricts the sample to the 130 municipalities where the winner in the 2004 election was from parties in the coalition and the runner-up was from parties in the opposition. Row 3 restricts the sample to 134 municipalities where the winner was not from a party in the Presidential coalition and the runner-up was from a party in the Presidential coalition. Standard errors are clustered at the municipality level. Row 4 restricts the sample to 100 municipalities where both the winner and the runner-up were not from a party in the Presidential coalition. Standard errors are clustered at the municipality level. ${ }^{*} p \leq .10,{ }^{* *} p \leq .05,{ }^{* * *} p \leq .01$. 
Table 15: Balance test for Mayors elected in 1996 - Polynomial (4)

\begin{tabular}{lclr}
\hline \multicolumn{1}{c}{ Method } & Jump at 50\% & SE & No. Observations \\
\hline Elected Mayor in 2000 & -0.00 & $(0.03)$ & 10444 \\
\hline Education & 0.02 & $(0.03)$ & 7046 \\
Married & 0.03 & $(0.03)$ & 7014 \\
Age & -0.24 & $(0.57)$ & 9075 \\
Gender & 0.03 & $(0.01)^{* *}$ & 7076 \\
President's Coalition & 0.00 & $(0.02)$ & 10444 \\
\hline
\end{tabular}

Note: This sample comprises 10444 politicians who participated in the 1996 mayoral election and either won or were the runner up. The forcing variable is Vote margin - the difference of votes in percentage terms between the winner and the runner up. The discontinuity is estimated at Vote margin $=0$ with a 4-degree polynomial on each side of the cutoff. Standard errors are clustered at the municipality level. ${ }^{*} p \leq .10$, ${ }^{* *} p \leq .05,{ }^{* * *} p \leq .01$. 
Table 16: Balance test for Mayors elected in 2000 - Polynomial (4)

\begin{tabular}{lclr}
\hline \multicolumn{1}{c}{ Method } & Jump at 50\% & SE & No. Observations \\
\hline Elected Mayor in 2004 & -0.09 & $(0.04)^{* *}$ & 6964 \\
\hline Education & -0.02 & $(0.03)$ & 6884 \\
Married & 0.04 & $(0.03)$ & 6916 \\
Age & 1.46 & $(0.64)^{* *}$ & 6960 \\
Gender & 0.00 & $(0.02)$ & 6962 \\
Presidents's Coalition in 2000 & -0.03 & $(0.03)$ & 6964 \\
\hline
\end{tabular}

Note: This sample comprises 6964 politicians who participated in the 2000 mayoral election and either won or were the runner up. This samples does not include municipalities where the incumbent Mayor in 2004 faced a two-term limit. The forcing variable is Vote margin - the difference of votes in percentage terms between the winner and the runner up. The discontinuity is estimated at Vote margin $=0$ with a 4-degree polynomial on each side of the cutoff. Standard errors are clustered at the municipality level. ${ }^{*} p \leq .10,{ }^{* *} p \leq .05,{ }^{* * *} p \leq .01$. 
Table 17: Balance test for Mayors elected in 2004 - Polynomial (4)

\begin{tabular}{lclr}
\hline \hline \multicolumn{1}{c}{ Method } & Jump at 50\% & SE & No. Observations \\
\hline Elected Mayor in 2008 & 0.10 & $(0.03)^{* * * *}$ & 8092 \\
\hline Education & 0.00 & $(0.02)$ & 8017 \\
Single & -0.02 & $(0.02)$ & 8027 \\
Age & 0.28 & $(0.56)$ & 8084 \\
Gender & 0.00 & $(0.02)$ & 8040 \\
President's Coalition & -0.01 & $(0.03)$ & 8092 \\
\hline
\end{tabular}

Note: Total sample 8090; This sample comprises 8092 politicians who participated in the 2004 mayoral election and either won or were the runner up. This samples does not include municipalities where the incumbent Mayor faced a two-term limit in 2008. The forcing variable is Vote margin - the difference of votes in percentage terms between the winner and the runner up. The discontinuity is estimated at Vote margin $=0$ with a 4 -degree polynomial on each side of the cutoff. Standard errors are clustered at the municipality level. Standard errors are clustered at the municipality level. ${ }^{*} p \leq .10,{ }^{* *} p \leq .05,{ }^{* * *} p \leq .01$.

Table 18: Balance test for Federal Deputies - Polynomial (4)

\begin{tabular}{lclr}
\hline \hline \multicolumn{1}{c}{ Method } & Jump at 50\% & SE & No. Observations \\
\hline Elected Federal Deputy in t+4 & 0.25 & $(0.06)^{* * *}$ & 728 \\
\hline Education & 0.01 & $(0.02)$ & 720 \\
Single & 0.04 & $(0.03)$ & 724 \\
Age & 0.63 & $(0.82)$ & 727 \\
Gender & -0.01 & $(0.03)$ & 728 \\
\hline
\end{tabular}

Note: This sample comprises 728 politicians who participated in the Federal Deputy election and either were close winner or close loser within the coalition. The discontinuity is estimated at Vote margin $=0$ with a 4-degree polynomial on each side of the cut-off. Standard errors are clustered at the state level. ${ }^{*} p \leq .10,{ }^{* *} p \leq .05$, ${ }^{* * *} p \leq .01$. 
Table 19: Balance test for State Deputies - Polynomial (4)

\begin{tabular}{lclr}
\hline \multicolumn{1}{c}{ Method } & Jump at $50 \%$ & SE & No. Observations \\
\hline Elected State Deputy in t+4 & 0.13 & $(0.04)^{* * *}$ & 1270 \\
\hline Education & -0.01 & $(0.03)$ & 1251 \\
Single & -0.03 & $(0.03)$ & 1262 \\
Age & 1.46 & $(0.83)^{*}$ & 1270 \\
Gender & 0.01 & $(0.02)$ & 1251 \\
\hline
\end{tabular}

Note: This sample comprises 1270 politicians who participated in the State Deputy election and either were close winner or close loser within the coalition. The discontinuity is estimated at Vote margin $=0$ with a 4-degree polynomial on each side of the cut-off. Standard errors are clustered at the state level. ${ }^{*} p \leq .10,{ }^{* *} p \leq .05$, ${ }^{* * *} p \leq .01$.

Table 20: Balance test for Councillors - Polynomial (4)

\begin{tabular}{lclr}
\hline \multicolumn{1}{c}{ Method } & Jump at 50\% & SE & No. Observations \\
\hline Elected Councillor in t+4 & 0.001 & $(0.006)$ & 80696 \\
\hline Education & 0.002 & $(0.005)$ & 79378 \\
Single & -0.02 & $(0.004)^{* * *}$ & 79866 \\
Age & 0.25 & $(0.11)^{* *}$ & 80346 \\
Gender & 0.002 & $(0.004)$ & 80678 \\
\hline
\end{tabular}

Note: This sample comprises 80696 politicians who participated in the Councillor election and either were close winner or close loser within the coalition. The discontinuity is estimated at Vote margin $=0$ with a 4 -degree polynomial on each side of the cut-off. Standard errors are clustered at the municipality level. ${ }^{*} p \leq .10,{ }^{* *} p \leq .05$, ${ }^{* * *} p \leq .01$. 
Table 21: Multi-Office Incumbency Advantage for Mayors Restricted to 330 Municipalities- Polynomial (4)

\begin{tabular}{lclr}
\hline \hline \multicolumn{1}{c}{ Method } & Jump at $50 \%$ & SE & No. Observations \\
\hline State legislator t+2 years & -0.221 & $(0.031)^{* * *}$ & 1312 \\
Federal legislator t+2 years & -0.086 & $(0.026)^{* * *}$ & 1312 \\
Senator t+2 years & -0.014 & $(0.012)$ & 1312 \\
Governor t+2 years & -0.003 & $(0.005)$ & 1312 \\
Councillor t+4 years & -0.02 & $(0.019)$ & 1312 \\
Mayor t+4 years & 0.232 & $(0.086)^{* * *}$ & 1312 \\
Multi-office success (t+4) & & & 900 \\
\hline State legislator t+6 years & -0.048 & $(0.052)$ & 900 \\
Federal legislator t+6 years & 0.033 & $(0.019)$ & 900 \\
Senator t+6 years & 0.001 & $(0.001)$ & 900 \\
Governor t+6 years & 0.009 & $(0.008)$ & 900 \\
Multi-office success (t+6) & & & 900 \\
\hline Councillor t+8 years & 0.001 & $(0.017)$ & \\
Mayor t+8 years & -0.072 & $(0.054)$ & \\
\hline
\end{tabular}

Note: This sample comprises 1312 politicians who participated in the 1996, 2000 and 2004 mayoral election and either won or were the runner up. The forcing variable is Vote margin - the difference of votes in percentage terms between the winner and the runner up. The discontinuity is estimated at Vote margin $=0$ with a 4-degree polynomial on each side of the cutoff. Standard errors are clustered at the municipality level. ${ }^{*} p \leq .10,{ }^{* *} p \leq .05,{ }^{* * *} p \leq .01$. 
Table 22: Next office attempted by current politicians.

\begin{tabular}{|c|c|c|c|c|c|c|c|c|c|c|}
\hline To: & Councillor & Mayor & Vice-Mayor & State Deputy & Federal Deputy & Senator & Sup. Senator & Governor & Vice-Governor & No office \\
\hline \multicolumn{11}{|l|}{ From: } \\
\hline Councillor & 0.726 & 0.023 & 0.047 & 0.02 & 0.005 & 0 & 0 & 0 & 0 & 0.179 \\
\hline Mayor & 0.013 & 0.619 & 0.014 & 0.023 & 0.008 & 0.001 & 0.001 & 0.002 & 0.001 & 0.381 \\
\hline Vice-Mayor & 0.123 & 0.175 & 0.284 & 0.022 & 0.009 & 0.001 & 0 & 0 & 0 & 0.387 \\
\hline State Deputy & 0.004 & 0.169 & 0.018 & 0.619 & 0.067 & 0.003 & 0.002 & 0.003 & 0.001 & 0.1 \\
\hline Federal Deputy & 0.006 & 0.16 & 0.02 & 0.016 & 0.619 & 0.04 & 0.006 & 0.017 & 0.016 & 0.1 \\
\hline Senator & 0 & 0.062 & 0 & 0.012 & 0.025 & 0.28 & 0 & 0.342 & 0.031 & 0.211 \\
\hline Sup. Senator & 0.088 & 0.034 & 0 & 0.013 & 0.005 & 0.025 & 0.113 & 0 & 0 & 0.675 \\
\hline Governor & 0 & 0.02 & 0 & 0.01 & 0.031 & 0.225 & 0 & 0.52 & 0 & 0.174 \\
\hline Vice-Governor & 0 & 0.068 & 0 & 0.136 & 0.068 & 0.046 & 0.046 & 0.21 & 0.182 & 0.25 \\
\hline
\end{tabular}

Notes: Columns refer to office gained in next election cycle i.e. in next four years and rows refer to office won in a election. Therefore cells refer to transition probabilities. Sample consists of pooled elections; years 1994, 1998, 2002, 2006, and 2010 for State Deputy, Federal Deputy Governor and Senator elections, and years 1996, 2000, 2004, and 2008 for Councillor and Mayoral elections. 
Table 23: Next office held by politicians from 1994 and 1996 elections

\begin{tabular}{|c|c|c|c|c|c|c|c|c|c|c|}
\hline To: & Councillor & Mayor & Vice-Mayor & State Deputy & Federal Deputy & Senator & Sup. Senator & Governor & Vice-Governor & No office \\
\hline \multicolumn{11}{|l|}{ From: } \\
\hline Councillor & 0.445 & 0.01 & 0.01 & 0.003 & 0.001 & 0 & 0 & 0 & 0 & 0.532 \\
\hline Mayor & 0.015 & 0.437 & 0.014 & 0.006 & 0.002 & 0 & 0 & 0.004 & 0.004 & 0.518 \\
\hline State Deputy & 0.022 & 0.12 & 0.002 & 0.482 & 0.051 & 0.004 & 0.001 & 0.003 & 0.002 & 0.301 \\
\hline Federal Deputy & 0.023 & 0.076 & 0.004 & 0.023 & 0.571 & 0.006 & 0.002 & 0.002 & 0.002 & 0.285 \\
\hline Senator & 0.019 & 0.047 & 0 & 0 & 0.148 & 0.278 & 0.037 & 0.093 & 0 & 0.352 \\
\hline Governor & 0 & 0 & 0 & 0 & 0.074 & 0.185 & 0 & 0.407 & 0 & 0.333 \\
\hline
\end{tabular}

Notes: Columns refer to next office gained and rows refer to office won in a election. Therefore cells refer to transition probabilities. Sample consists of politicians who won election in year 1994 for State Deputy, Federal Deputy, Governor and Senator elections, and in 1996 for Councillor and Mayoral elections. 
Table 24: Next office held by politicians from 1998 and 2000 elections

\begin{tabular}{|c|c|c|c|c|c|c|c|c|c|c|}
\hline To: & Councillor & Mayor & Vice-Mayor & State Deputy & Federal Deputy & Senator & Sup. Senator & Governor & Vice-Governor & No office \\
\hline \multicolumn{11}{|l|}{ From: } \\
\hline Councillor & 0.413 & 0.011 & 0.03 & 0.003 & 0.001 & 0 & 0 & 0 & 0 & 0.543 \\
\hline Mayor & 0.01 & 0.323 & 0.015 & 0.019 & 0.008 & 0.001 & 0 & 0.001 & 0.001 & 0.623 \\
\hline State Deputy & 0.02 & 0.069 & 0.012 & 0.519 & 0.061 & 0.006 & 0.002 & 0.001 & 0.003 & 0.308 \\
\hline Federal Deputy & 0.01 & 0.064 & 0.004 & 0.027 & 0.561 & 0.025 & 0 & 0.008 & 0.008 & 0.29 \\
\hline Senator & 0.037 & 0.037 & 0 & 0 & 0.037 & 0.296 & 0 & 0.074 & 0 & 0.519 \\
\hline Governor & 0 & 0.074 & 0 & 0 & 0.185 & 0.259 & 0 & 0.259 & 0 & 0.222 \\
\hline
\end{tabular}

Notes: Columns refer to next office gained and rows refer to office won in a election. Therefore cells refer to transition probabilities. Sample consists of politicians who won election in year 1998 for State Deputy, Federal Deputy, Governor and Senator elections, and in 2000 for Councillor and Mayoral elections. 
Table 25: Next office held by politicians from 2002 and 2004

\begin{tabular}{|c|c|c|c|c|c|c|c|c|c|c|}
\hline To: & Councillor & Mayor & Vice-Mayor & State Deputy & Federal Deputy & Senator & Sup. Senator & Governor & Vice-Governor & No office \\
\hline \multicolumn{11}{|l|}{ From: } \\
\hline Councillor & 0.398 & 0.006 & 0.023 & 0.002 & 0.001 & 0 & 0 & 0 & 0 & 0.57 \\
\hline Mayor & 0.002 & 0.386 & 0.001 & 0.008 & 0.003 & 0 & 0 & 0 & 0 & 0.599 \\
\hline Vice-Mayor & 0.058 & 0.074 & 0.205 & 0.003 & 0.001 & 0 & 0 & 0 & 0 & 0.658 \\
\hline State Deputy & 0.013 & 0.07 & 0.017 & 0.522 & 0.053 & 0.001 & 0.002 & 0 & 0.006 & 0.317 \\
\hline Federal Deputy & 0.018 & 0.047 & 0.012 & 0.008 & 0.526 & 0.012 & 0.006 & 0.004 & 0.004 & 0.365 \\
\hline Senator & 0 & 0.019 & 0 & 0.019 & 0.056 & 0.241 & 0 & 0.056 & 0.037 & 0.574 \\
\hline Sup. Senator & 0.019 & 0.019 & 0 & 0 & 0.019 & 0.019 & 0.093 & 0 & 0 & 0.833 \\
\hline Governor & 0 & 0.037 & 0 & 0.037 & 0 & 0.259 & 0 & 0.333 & 0 & 0.333 \\
\hline Vice-Governor & 0 & 0 & 0 & 0.074 & 0.111 & 0 & 0.037 & 0.037 & 0.111 & 0.63 \\
\hline
\end{tabular}

Notes: Columns refer to next office gained and rows refer to office won in a election. Therefore cells refer to transition probabilities. Sample consists of politicians who won election in year 2002 for State Deputy, Federal Deputy, Governor and Senator elections, and in 2004 for Councillor and Mayoral elections. 
Table 26: Next office held by politicians from 2006 elections

\begin{tabular}{|c|c|c|c|c|c|c|c|c|c|c|}
\hline To: & Councillor & Mayor & Vice-Mayor & State Deputy & Federal Deputy & Senator & Sup. Senator & Governor & Vice-Governor & No office \\
\hline \multicolumn{11}{|l|}{ From: } \\
\hline State Deputy & 0 & 0.039 & 0.002 & 0.494 & 0.052 & 0 & 0.003 & 0 & 0.003 & 0.406 \\
\hline Federal Deputy & 0 & 0.024 & 0.004 & 0.006 & 0.497 & 0.028 & 0.004 & 0 & 0.004 & 0.434 \\
\hline Senator & 0 & 0 & 0 & 0 & 0 & 0 & 0 & 0.154 & 0 & 0.846 \\
\hline Sup. Senator & 0.039 & 0 & 0 & 0 & 0.039 & 0 & 0 & 0 & 0 & 0.923 \\
\hline Governor & 0 & 0 & 0 & 0 & 0 & 0.294 & 0 & 0.177 & 0 & 0.529 \\
\hline Vice-Governor & 0 & 0.059 & 0 & 0.059 & 0 & 0.059 & 0 & 0.177 & 0.059 & 0.588 \\
\hline
\end{tabular}

Notes: Columns refer to next office gained and rows refer to office won in a election. Therefore cells refer to transition probabilities. Sample consists of politicians who won election in year 2006 for State Deputy, Federal Deputy, Governor and Senator elections. 
Table 27: Mayor RDD Sample Munincipality Characteristics

\begin{tabular}{lccc}
\hline RDD Sample Year & 1996 & 2000 & 2004 \\
\hline Literacy rate & 0.81 & 0.83 & 0.81 \\
S.E. & 0.005 & 0.007 & 0.006 \\
$\mathrm{~N}$ & 551 & 385 & 488 \\
\hline Urban & 0.57 & 0.59 & 0.57 \\
S.E. & 0.01 & 0.013 & 0.012 \\
N & 551 & 385 & 488 \\
\hline Water & 0.57 & 0.58 & 0.57 \\
S.E. & 0.01 & 0.015 & 0.012 \\
N & 551 & 385 & 488 \\
\hline Electricity & 0.87 & 0.87 & 0.86 \\
S.E. & 0.007 & 0.01 & 0.009 \\
N & 551 & 385 & 488 \\
\hline Population & 21445.3 & 18577.8 & 18229.2 \\
S.E. & 1441.08 & 2082.83 & 1405.93 \\
N & 551 & 385 & 488 \\
\hline \hline
\end{tabular}

Notes: Data from the 2000 Census. 